\title{
EHMTI-0111. Intra-variability of migraine attacks features
}

\author{
M Viana ${ }^{1 *}$, G Sances ${ }^{1}$, N Ghiotto ${ }^{1}$, E Guaschino ${ }^{1}$, M Allena ${ }^{1}$, M Allena ${ }^{1}$, G Nappi ${ }^{1}$, C Tassorelli ${ }^{1}$, PJ Goadsby ${ }^{2}$ \\ From 4th European Headache and Migraine Trust International Congress: EHMTIC 2014 \\ Copenhagen, Denmark. 18-21 September 2014
}

\section{Background}

Migraine attacks may have different feature with respect to different patients but also within the same patient. At the best of our knowledge in literature is not described the percentage of patients that report attacks as stereotyped and the percentage of patients reporting attacks with different phenotype.

\section{Aim}

To evaluate the percentage of migraine patients reporting attacks with same characteristics on three consecutive attacks.

\section{Methods}

Each patient recorded in a diary the features of three consecutive attacks. Characteristics recorded were: pain intensity on a 4 point scale, presence of nausea $(\mathrm{N})$, vomiting $(\mathrm{V})$, photophobia (PT), phonophophia (PN), osmophobia (O), allodynia (A), cranial autonomic symptoms (CAS) (at least one), premonitory symptoms (at least one). Patients were allowed to take a medication (triptan).

\section{Results}

In 30 patients, nobody presented identical characteristic on the three studied attacks. Results remained the same if we do not consider the pain intensity and the presence of at least one premonitory symptoms (0 out of 30 patients). If we consider only the presence of associated symptoms $(\mathrm{N}, \mathrm{V}, \mathrm{PT}, \mathrm{PN}, \mathrm{O}, \mathrm{A}, \mathrm{CAS}), 3$ out of 30 patients had the same phenotype on three different attacks, while if we consider only the presence/absence of N, V, PT, PN, 9 out of 30 patients $(30 \%)$ had three identical attacks. Triptan intake occurred at a mean of 63 minutes after pain onset when the average pain intensity was 2 .

${ }^{1}$ Headache Science Center, C. Mondino National Neurological Institute, Pavia, Italy

Full list of author information is available at the end of the article

\section{Conclusion}

Migraine attacks are very different not just among patients, but also in the same patient. Our data indicates that stereotypy of attacks is uncommon.

No conflict of interest.

\section{Authors' details}

${ }^{1}$ Headache Science Center, C. Mondino National Neurological Institute, Pavia, Italy. ${ }^{2}$ Headache Group - NIHR-Wellcome Trust Clinical Research Facility, King's College London, London, UK.

Published: 18 September 2014

doi:10.1186/1129-2377-15-S1-D70

Cite this article as: Viana et al.: EHMTI-0111. Intra-variability of migraine attacks features. The Journal of Headache and Pain 2014 15(Suppl 1):D70.

\section{SpringerOpen ${ }^{\circ}$}

(C) 2014 Viana et al; licensee Springer. This is an Open Access article distributed under the terms of the Creative Commons Attribution License (http://creativecommons.org/licenses/by/2.0), which permits unrestricted use, distribution, and reproduction in any medium, provided the original work is properly cited.
Submit your manuscript to a SpringerOpen ${ }^{\circ}$ journal and benefit from:

- Convenient online submission

- Rigorous peer review

- Immediate publication on acceptance

- Open access: articles freely available online

- High visibility within the field

- Retaining the copyright to your article

Submit your next manuscript at $>$ springeropen.com 